\title{
US Leadership and the International Refugee Regime
}

\author{
SUSAN F. MARTIN AND ELIZABETH FERRIS
}

\section{Abstract}

This article examines the role of the United States in the international refugee regime. It argues that the United States generally leads in assistance and protection of refugees and displaced persons when three conditions are present: a strong link to us foreign policy; clear and highly visible humanitarian needs and important domestic constituencies in support of action; and strong congressional support. The United States manifests its leadership through its financial contributions, as the largest donor to the array of international organizations with responsibilities in this area; resettlement of the refugees; and the use of the convening power of the us government. Nevertheless, there are reasons to be cautious about us leadership. While it is unlikely that the United States will soon lose its status as principal donor and principal strategist on tackling displacement, its ability to generate new resettlement offers is less clear, as is its ability to increase its own resettlement levels. The asylum system still has significant gaps, making it difficult for the United States to lead by example.

\section{Résumé}

Cet article examine le rôle que jouent les États-Unis (É.-U.) vis-à-vis du régime international des réfugiés. Il défend l'idée que les États-Unis jouent généralement un rôle de leader actif en matière d'assistance et de protection apportées aux réfugiés et aux personnes déplacées quand trois conditions sont remplies: l'existence d'un lien solide avec la politique étrangère des É.-U., un solide soutien du Congrès, et la coexistence de besoins humanitaires manifestes et particulièrement visibles et d'importantes parties prenantes nationales pour soutenir leur action. En tant que principal donateur des organismes internationaux responsables dans ce domaine, les É.-U. expriment leur leadership par leurs contributions financières, mais aussi en réinstallant les réfugiés et en faisant appel au pouvoir de mobilisation de leur gouvernement. Il existe néanmoins des raisons dêtre vigilant vis-à-vis de leur leadership. Même s'il est peu probable qu'ils perdent dans un avenir proche leur statut de principal donateur et leur place parmi les principaux stratèges de la problématique des déplacements, leur capacité à offrir de nouveaux sites de réinstallation est moins évidente que celle de développer leurs propres sites. Le régime diasile comporte encore d'importantes lacunes, qui rendent difficiles pour les É.-U. de diriger par l'exemple.

\section{Introduction}

7 his article examines the role of the United States in the international refugee regime. While the United States has been a strong supporter of multilateral institutions in issues that range from trade to health to security, this support has never been unconditional or absolute. ${ }^{1}$ There are many examples where the United States has used the United Nations to advance its foreign policy interests, but also many other instances where the United States has acted unilaterally and, rather than relying on multilateral structures, has turned to hand-picked "coalitions of the willing" to advance its foreign policy interests. ${ }^{2}$ So, too, us policy toward the international refugee regime has been ambivalent: on the one hand, us support for multilateral governance of global refugee issues has been crucial. On the other hand, the United States has sometimes taken unilateral actions in ways that have weakened this international order.

The United States has ratified the principal instruments that protect refugees; offers substantial financial support to the UN High Commissioner for Refugees (UNHCR) and other 
international humanitarian organizations; accepts tens of thousands of refugees each year for permanent resettlement; provides asylum and temporary protection to still further persons arriving spontaneously on its territory; has systems that offer protection to victims of trafficking; and has pledged to help reduce statelessness. While the United States is thus often identified as a key proponent of an effective international system for assistance and protection of refugees and forced migrants, its policies on refugees and other forced migrants, particularly those seeking to arrive on its borders, have sometimes weakened the international refugee regime. Nor has its support for multilateral approaches to refugee assistance and protection been consistent; as discussed in the following sections, at times the United States has relied on unilateral policies, whereas at others it has cooperated with other governments and international organizations to improve responses to refugee crises.

This article considers the factors that explain when the United States chooses to act multilaterally through the institutions and decision-making procedures of the global refugee regime. By considering the history of us engagement in global refugee issues, we argue that the United States chooses to be an active and influential member of the global refugee regime when several conditions come together. First, when there have been strong foreign policy linkages to crises that produce refugees, and the refugees themselves are seen as a manifestation of us policy interests, the United States has been more willing to take action and influence the decisions of others. Second, clear and highly visible humanitarian needs and important domestic constituencies in support of action to address those needs help mobilize us leadership. Third, strong congressional backing of presidential decisions to exert us leadership facilitates those actions, especially when new resources must be appropriated in support of proactive policies and programs.

This article begins with discussion of the historical role of the United States in protection of refugees. It then focuses specifically on us leadership during the Cold War as the current refugee regime was established. The following section discusses the evolution in us attitudes towards the international organizations mandated to assist and protect refugees and displaced persons. The current mechanisms by which the United States exercises leadership internationally are then examined, focusing on three policy frameworks: (1) financial support to the international refugee system; (2) admission of refugees and others in need of international protection; and (3) use of its convening power to mobilize support for solutions for refugees and concrete commitments by other states. The article concludes with an assessment of current us leadership and likely role in the future.

\section{The Historical Role of the United States in Refugee Protection}

The United States is the quintessential nation of immigrants, founded in large part by people seeking safety from persecution and religious intolerance, albeit often in turn displacing indigenous populations living in settlement areas. From the seventeenth century through the first decade of the twentieth, the United States provided a safety net for millions of refugees, mostly from Europe, through its largely open door immigration policies. While providing no specific admissions priority or distinctions for those whom we would now identify as refugees, us policies on religious toleration and the Constitutional Bill of Rights proved to be a strong draw for those fleeing persecution, especially on the basis of their religion, ethnicity, and political opinions.

The first specific mention of flight from persecution as a basis for special treatment in us immigration law appeared in 1917 when legislation was passed requiring new immigrants to be literate in their native language. Persons fleeing religious persecution in their home countries, either by law or practice, were explicitly exempted from the requirement. ${ }^{3}$ In vetoing the legislation, President Woodrow Wilson stated his opposition to the literacy requirement in general but also cited problems with the exemption. He had previously criticized the literacy test as an affront to the United States as an asylum for the persecuted, but he found the formulation of the refugee exemption troubling. It would require the us government to pass judgment on the actions of another government, potentially causing "very serious questions of international justice and comity" 4

The United States shifted its immigration policies more significantly in the 1920 s towards more restrictive standards. ${ }^{5}$ For the first time, the country adopted overall numerical ceilings on admission and established national origins quotas that made it all but impossible for immigrants from Eastern and Southern Europe to enter. The legislation also confirmed the bars on admission of immigrants from Asia that had been adopted in 1882. No exceptions were made for refugees. In fact, during the Great Depression, administrative actions made it even more difficult for refugees to enter than other immigrants. ${ }^{6}$

us leadership internationally on refugees also flagged during this period. While the United States was the driving force behind the Evian Conference in 1938 to address the situation of refugees from Nazi Germany, the United States failed to make concrete commitments to accept refugees. The conference had a dual mission: to encourage countries to resettle refugees and to persuade Germany to establish an orderly emigration process. Although there was much sympathy expressed for the refugees, few concrete proposals came out 
of the conference. From the beginning it was clear that little would happen at the conference. In calling for the conference, us President Franklin Roosevelt made it clear that he was not asking any country, including the United States, to change its refugee policy. Subsequently, no government pledged to resettle significant numbers of refugees (except for the Dominican Republic's rather vague offer). After the conference, in a speech to the Party Congress in Nuremberg in September 1938, Adolf Hitler pointed to the hypocrisy of the countries that condemned Germany's policies but would not admit Jewish refugees: "Lamentations have not led these democratic countries to substitute helpful activity at last for their hypocritical questions; on the contrary, these countries with icy coldness assured us that obviously there was no place for the Jews in their territory."7 This recognition that other countries would do little to save the Jews and other refugees paved the way for the Holocaust.

\section{us Refugee Policy during the Cold War}

After the Second World War, with concerns growing about Soviet dominance of Eastern Europe and the large number of refugees in still unstable Western Europe, the United States began to adopt a series of administrative and legislative actions for the admission of refugees and displaced persons outside of the numerical limits and national origins quotas that remained in us legislation. us policy on refugees throughout the Cold War was developed to support us foreign policy interests and enjoyed strong bipartisan support in Congress. President Harry Truman signed a directive on 22 December 1945 that outlined new administrative procedures to facilitate the admission of war victims into the United States. In 1948, Congress took action to expand admissions of displaced persons. The 1948 Act allowed the admission of 220,000 displaced persons. They were to be admitted within existing quotas, so as not to raise questions about underlying law, but provisions were made to borrow, or mortgage, up to 50 per cent of a country's annual numbers to facilitate the additional admissions. In 1950, proponents of more liberal immigration provisions were able to amend the Displaced Persons Act to increase the number of available visas and lessen some of the more restrictive aspects. The numbers to be admitted increased to 415,000, but maintained the "mortgaging" provisions. It eliminated preferences for persons engaged in agriculture and for those from the Baltic countries. It allowed admission to those who had entered displaced persons camps after 1945. Further legislation followed. The Refugee Relief Act of 1953 offered 205,000 entry slots, this time without borrowing from the national origins quotas.

The Refugee Relief Act went beyond the displaced persons legislation in covering "any person in a country or area which is neither Communist nor Communist dominated, who because of persecution, fear of persecution, natural calamity or military operation is out of his usual place of abode and unable to return thereto, who has not been firmly resettled, and who is in urgent need of assistance for the essentials of life or for transportation." The legislation defined an escapee as any refugee who had fled a Communist country. The Refugee Relief Act expired just after the country was called to respond to the next refugee crisis - the flight of refugees after the abortive Hungarian Revolution in 1956. The president authorized use of 6,500 of the Refugee Relief Act visas for the Hungarians before its expiration. Others would be admitted under a provision in the McCarran-Walters Act that allowed the attorney general to allow foreign nationals to enter under his own authority. Called the parole authority, ${ }^{8}$ it was used to permit about 38,00o Hungarians to enter the United States between the end of 1956 and May 1957. Again, the United States demonstrated flexibility in applying existing legislation to support its foreign policy objectives. In September 1957, new legislation was passed that permitted allocation of visa numbers that had been authorized but not used in the Refugee Relief Act. This legislation, the Refugee Escapee Act, defined refugee-escapees as persons fleeing Communist or Communist-dominated countries or countries in the Middle East because of persecution or a well-founded fear of persecution based on racial, religious, or political grounds. ${ }^{9}$ Although using persecution criteria found in the 1951 Refugee Convention, the us legislation restricted the refugee definition to those it found ideologically compatible-persons fleeing persecution by Communist regimes.

The parole authority also continued to be to address specific refugee emergencies. The Refugee Fair Share Act in 1960 authorized its use for a limited number of refugees. When the Cuban revolution installed a Communist regime, however, the United States opened its doors to one of the largest groups admitted under the parole authority. Unlike the European refugees, the Cubans initially came on their own, often on tourist visas. American policy was to parole them into the country, and then, under the Cuban Adjustment Act of 1966 , to convert their status to permanent resident. Later in the 196os, the United States and Cuba would negotiate an airlift that brought the Cubans directly to the United States. This pattern continued in the 1970s. The parole authority was used to admit large numbers of refugees from Southeast Asia and the former Soviet Union. ${ }^{10}$ Only when the Refugee Act of 1980 was enacted did the United States establish a permanent system for admission of refugees to be resettled into the country, as discussed below.

\section{Us Engagement with International Organizations}

In the years during and after the Second World War, the United States initially supported but showed great skepticism 
about the multilateral organizations established to address what was often called the "refugee problem." Although a strong supporter of the newly formed United Nations and a principal architect of the Universal Declaration of Human Rights, the us government was concerned about the high cost of the multilateral programs. In 1943, at the urging of the us government, the UN Relief and Rehabilitation Administration (UNRRA) was established to give aid to areas liberated from the Axis powers. UNRRA acted in conjunction with the military authorities and local officials in providing relief to civilians, including those who had been displaced. Its scope of operation in Europe was Austria, Germany, Italy, and certain areas in Africa and the Near East. It was also responsible for relief in China and other areas occupied by Japan. Its budget was nearly $\$ 3.4$ billion, with the United States contributing \$2.8 billion. ${ }^{11}$ Over time, however, the United States became increasingly dissatisfied with these costs, especially those that supported repatriation of displaced persons to Eastern European countries that were by then under the control of the Soviet Union.

Succeeding UNRRA was the International Refugee Organization (IRO) established by the General Assembly in December 1946. The IRo Constitution defined refugees as persons who belonged to one of several categories:

- Victims of the Nazi or fascist regimes or of regimes that took part on their side in the Second World War, or of the quisling or similar regimes that assisted them against the United Nations, whether enjoying international status as refugees or not;

- Spanish Republicans and other victims of the Falangist regime in Spain, whether enjoying international status as refugees or not;

- Persons who were considered "refugees" before the outbreak of the Second World War, for reasons of race, religion, nationality, or political opinion. ${ }^{12}$

The IRO provided assistance to about 1.6 million displaced persons, including those still in camps and others who were spontaneously settled. The organization helped resettle about one million refugees to third countries. By contrast, only 54,000 refugees received assistance in repatriating to their home country. ${ }^{13}$

Despite the success of the agency, about 400,000 refugees, many old and infirm, remained in displaced persons camps in 1950. The us Congress made clear that it did not intend to continue to fund the IRO and expected the European countries to assume the costs of the residual refugee population. Marshall Plan funds could be used to shore up their capacities to accomplish this goal. Consequently, the IRO was disbanded, to be succeeded by the UNHCR.

The Us government was not an early supporter of UNHCR. It preferred to resettle refugees through its own resettlement programs, finding them less costly and more consistent with us priorities. Congress had also passed legislation precluding use of migration and refugee funds for organizations with Communist members. Though not focused specifically on UNHCR, whose members were mostly non-Communist governments, this Cold War provision undermined us participation in a range of UN initiatives related to refugees and migrants. ${ }^{14}$ More specific to UNHCR were Us concerns about its leadership. UN High Commissioner van Heuven Goedhart had been appointed over us objections, which may have contributed to its reluctance to support the organization he directed. ${ }^{15}$ But funding continued to be an issue. The United States blocked an attempt by the first high commissioner to establish a un Refugee Emergency Fund, though the General Assembly authorized him in 1952 to raise \$3 million for such a fund. Even that authorization was for new emergencies, not to support the refugees already under his mandate-many of whom were ineligible for resettlement and in dire need of relief. The United States again argued that the Marshall Plan provided sufficient resources for the care of refugees. Suffice it to say, in the absence of the largest donor of the United Nations and the largest resettlement country, UNHCR had a monumental task. Moreover, at this time, UNHCR was not an operational agency but rather was intended to focus on protection of refugees in Europe.

In light of these developments, the United States and Belgium co-hosted a conference in Brussels to identify what additional efforts were needed to resolve the situation of refugees and others who wished to migrate. The Brussels conference brought together representatives of twenty-three countries, which Edward O'Connor, the head of the Us Displaced Persons Commission, divided into four categories: (1) countries of emigration (e.g., Germany, Italy, Netherlands, Austria, and Greece); (2) countries of immigration (e.g., Canada, Australia, Brazil, Chile, and Bolivia); (3) interested countries (neither emigration nor immigration) that recognized the seriousness of the problem (e.g., France, Belgium, Switzerland, Turkey, and Luxembourg); and (4) the United States, which had agreed to fund much of the initial budget of any new organization that might be formed. ${ }^{16}$

The conference resulted in the establishment of a Provisional Intergovernmental Committee for the Movement of Migrants from Europe in 1951, which was later named the Intergovernmental Committee for European Migration and still later, the International Organization for Migration. As participants such as O'Connor readily admitted, the new organization was intended to buttress the interests of the West against those of the Communist world. Only countries that believed in freedom of movement for their citizens could become members, which meant that Communist governments that restricted departures could not join. This 
provision not only complied with the congressional bar on funding of organizations that included Communist members, it gave a sense of community to countries that had disparate histories and experiences with migration. As with UNHCR, the organization was supposed to finish its work in three years, but it too persisted into the present. In contrast to UNHCR's lack of operational engagement, from the beginning IOM was intended to serve its members and developed a strong operational capacity. Over the years, the United States turned to the IOM to provide operational support for refugee resettlement and to engage in many other tasks of interest to the US government.

The United States also exercised clear leadership in establishing two other international organizations that assisted refugees: the UN Relief and Works Administration for Palestinian Refugees (UNRWA) and the UN Korean Rehabilitation Administration (UNKRA).

UNRWA was established in 1949 to provide assistance and employment opportunities for Palestinian refugees. Until then, most aid was provided by the Red Cross and the American Friends Service Committee. UNRwA was asked specifically to take on two tasks. First, it was to carry out direct relief and works programs, and second, it was to consult with the host countries on measures to reduce the need for international assistance. These two tasks were consistent with the sense of the General Assembly, expressed in the 1949 Resolution creating UNRWA, that "continued assistance for the relief of the Palestine refugees is necessary to prevent conditions of starvation and distress among them and to further conditions of peace and stability, and that constructive measures should be undertaken at an early date with a view to the termination of international assistance for relief." 17 The United States was an early donor to UNRWA and continues as the principal bilateral supporter of its programs.

UNKRA was established by the General Assembly on 1 December 1950 as a "special authority with broad powers to plan and supervise rehabilitation and relief" in South Korea. ${ }^{18}$ According to a contemporary analysis, the United States was the leading proponent of the new organization and based its support on three principal assumptions:

First, the establishment of the agency was predicated on military success and an early cessation of hostilities ... Second, military success offered the prospect of creating a unified Korea under international auspices, an aim toward which United States policy had been directed since the liberation of the peninsula from Japanese control in 1945. And third, a unified Korea, striving for independence under the heavy burdens of military destruction, would require large sums of money in economic aid which the United States would be obliged to supply or risk losing Korea after winning the war. ${ }^{19}$
A multilateral agency, organized in the context of the United Nations, would help ensure that the costs of this endeavour would be shared with other countries.

The first two assumptions proved more elusive than anticipated, and the third was harder to achieve in the absence of an end to hostilities. As occurred during the Second World War, the military forces led by the United States retained broad authority over the relief operations occurring within their theatre of activities. Even after the truce ending the hostilities was signed, raising funds for UNKRA was difficult because other countries saw South Korea as being within the US sphere of interest. As such, the expectation was that the United States would fund the recovery. Nevertheless, in 1952 UNKRA began operations with a budget of $\$ 71$ million.

When the Soviet suppression of the Hungarian Revolution took place in 1956, the United States began to shift its views on UNHCR. The General Assembly asked UNHCR to use its good offices to assist and protect the refugees, even though they were not covered under the 1951 Refugee Convention (as the events causing their displacement occurred after 1951). Then, in 1957, UNHCR was called upon to respond to the refugee crises generated by the Algerian conflict and the continuing flow of people from mainland China into Hong Kong. These were both sensitive situations, as the interests of the permanent members of the Security Council were implicated-France in Algeria, and China (at that time the government in Taiwan held the seat) and Britain in Hong Kong. The organization was effective in its actions in each of these situations, and the United States, along with other major donors, allowed the growth of the organization's mandate and budget. Us support for UNHCR was directly related to the fact that it was useful to its foreign policy interests.

During the 1970s and 1980s, the United States was more than willing to fund UNHCR's operations when it served Us foreign policy goals. Refugee camps in Pakistan, Thailand, Honduras, and elsewhere became safe zones for the families of military forces fighting against the regimes in Afghanistan, Cambodia, and Nicaragua, respectively. At the same time, bipartisan political coalitions and important domestic constituencies in the United States generally supported expenditure of resources on refugees. For example, many veterans of the Vietnam conflict as well as religious and humanitarian organizations threw their support behind resettlement of refugees from Indochina. Culminating this period was us leadership in 1979 to develop a comprehensive approach to address the refugee crisis in Southeast Asia. Unlike the disastrous conference in Evian, the Geneva conference called by the United States was a resounding success. Vice-President Walter Mondale chaired the conference, demonstrating how seriously the United States government took the issue. The 
Us delegation came with a pledge to resettle at least 14,000 Indochinese refugees per month for whatever time it took to stabilize the situation. Its call for others to resettle refugees was met with widespread agreement. The conference also resulted in pledges from the countries of first asylum to keep their borders open and from Vietnam to establish an orderly departure program for those wanting to leave the country. us financial resources would back up the agreement.

Significantly, until the late 196os, the United States did not ratify the 1951 Convention on the Status of Refugees, preferring to operate under its own domestic refugee legislation rather than international standards. In 1968, however, the United States became party to the Convention by ratifying the 1967 Protocol. No new legislation was adopted, however, to implement us commitments under the Refugee Convention until 1980. In fact, in asking for ratification of the Protocol, the Executive Branch assured Congress that us law already included a non-refoulement (non-forcible return) provision, in the form of withholding of removal (referred to as withholding of deportation, until 1996). Withholding is mandatory for those who can demonstrate it is more likely than not that they will be persecuted if returned to their countries of origin unless they have committed an aggravated felony resulting in a prison sentence of five years or more. The Refugee Act of 1980 adopted the 1951 Convention definition of a refugee for the purposes of asylum and refugee resettlement, removing the language related to Communism. Through the remainder of the decade, however, the United States continued to give priority to admission of refugees from Communist countries.

\section{us Leadership Today}

The United States leads on refugee issues in two principal ways: as a donor and as a recipient of refugees. In the former case, the us focus is generally on assistance and protection for the millions of refugees and displaced persons who live in developing countries. In the latter case, the focus is on policies regarding admission and stay of those seeking protection within the United States. These policies are often seen as positive models for other countries, although there are cases-such as us policy of interdicting Haitians-that have served as models for deterrence policies taken by governments in other parts of the world.

United States and the International Refugee System

The United States remains the largest single contributor to international protection and assistance programs for refugees and internally displaced persons (IDPs), through support for UNHCR, UNRWA, IOM, the UN Office for the Coordination of Humanitarian Assistance, the World Food Program, and the principal non-governmental organizations assisting displaced populations. The United States is the largest donor to the UNHCR in absolute terms (almost US $\$ 1.5$ billion in 2016) and ranked eleventh on both a per capita and GDP basis. The United States provides general support as well as earmarked funds for specific programs. The United States also provides about Us $\$ 103$ million to IOM for its operational programs. The majority of these funds are earmarked for programs for displaced persons and refugee resettlement. Initiatives such as the evacuation of migrants from Libya have received special attention, with the United States contributing US\$27.1 million. The United States contributed US $\$ 360$ million to UNRWA as well. ${ }^{20}$ These numbers do not include the additional hundreds of millions spent on bilateral humanitarian assistance to governments and non-governmental organizations, much of which is spent on displaced persons.

Funding for refugees and displaced persons comes from two principal us agencies: the Bureau for Population, Refugees and Migration (BPRм) in the Us State Department, and the Office of Foreign Disaster Assistance (OFDA) in the us Agency for International Development. In general, BPRM is responsible for refugees and provides the majority of its support through multilateral organizations such as UNHCR, IOM, and UNRWA. OFDA is responsible for internally displaced persons and spends a higher proportion of its funding on bilateral assistance. As UNHCR and IOM have increased their support for internally displaced persons from both conflict and natural disasters, the lines between the two agencies' spheres of influence have blurred.

Beyond its funding, the United States also leads through its membership in the Executive Committee (ExCom) of the UNHCR and the governing councils of UNRWA and IOM, in addition to its important role as a permanent member of the Security Council. The ExCom was established by the UN Economic and Social Council (ECOsoc) and formally came into existence on 1 January 1959. ExCom is composed of UN member states who are elected by Ecosoc. ExCom's reports are submitted directly to the General Assembly; they do not substitute for policy guidance from Ecosoc and the General Assembly but play an important function in advising the high commissioner, reviewing funds and programs, authorizing the high commissioner to make appeals for funds, and approving proposed budget targets. The membership has grown from 25 to almost 100 members since its founding.

The United States plays an outsized role in ExCom. While it cannot always persuade other governments to follow its lead, it can effectively veto any conclusion that it opposes. As the largest donor, the United States has tremendous influence on UNHCR's finances and thus holds sway on issues that directly or indirectly involve funding. More often, though, the United States attempts to influence UNHCR practice through a positive use of its resources and ideas. The United 
States often uses ExCom to announce new initiatives to reform the way in which UNHCR operates. For example, at the 2013 ExCom, Deputy Secretary of State William Burns announced funding for Safe from the Start, a new initiative in keeping with longstanding us support for gender-friendly refugee policies: "Safe from the Start ... asks UNHCR, ICRC, and other aid agencies to add protection of women and girls to the short-list of priority actions at the onset of emergencies. Our new funding will enable our partners to hire specialized staff, conduct more training, and deploy new and innovative programs at the earliest stages of our response. Some of these measures will take time, but Safe from the Start can make a real difference in the near-term. We know we have many allies, but we look to others to join us in this important effort." 21

The United States also uses presidential statements at the General Assembly to draw attention to refugee issues. At the 2013 UN High Level Dialogue on Migration and Development, the United States pledged to co-chair the Migrants in Countries in Crisis initiative that would develop nonbinding guidance for countries of origin, transit, and destination on how best to address the situation of non-nationals affected by conflict and natural disasters. The United States was joined by the Philippines as co-chair, and Australia, Bangladesh, Costa Rica, Ethiopia, and the European Commission as members. The UN High Level Meeting on Large Scale Movements of Refugees and Migrants took note of the initiative and committed to "assist, impartially and on the basis of needs, migrants in countries that are experiencing conflicts or natural disasters, working, as applicable, in coordination with the relevant national authorities." 22 Just as the United States has used "coalitions of the willing" to support foreign policy interests, it has turned to "mini-multilateralism," 23 in pursuing specific humanitarian interests that fall outside existing international legal frameworks.

Most recently, President Barak Obama convened a us Leaders' summit on 20 September 2016, during the 2016 General Assembly meetings, to mobilize new commitments to the global refugee crisis. The announcement of this summit came immediately after the UN General Assembly decided to convene a high-level plenary on Large Movements of Refugees and Migrants on 19 September 2016. While the un meeting sought to improve multilateral responses to both refugees and migrants, the us initiative focused on three specific objectives with respect to refugees: (1) to increase humanitarian funding from \$10 billion in 2015 to $\$ 13$ billion in 2016 by identifying new donors and increasing donations among existing ones; (2) to double the number of refugees to be resettled by identifying new resettlement countries, expanding the resettlement commitments of resettlement countries, and providing other legal channels for humanitarian admission when resettlement provides insufficient access; and (3) to facilitate refugee inclusion and self-reliance to "enable refugees to meet their own needs and contribute to communities that host them." 24 In this regard, the United States sought and received commitments for more educational and work opportunities for refugees worldwide.

\section{Leading (or Not) by Example}

The United States leads through its own policies for admission of refugees and displaced persons. In some cases, it has been a model for positive policies that promote protection and solutions whereas in others, it has been a model for policies that impede protection.

Refugees and others needing international protection come to the United States in multiple ways. As discussed above, it has long resettled refugees, granting them permanent admissions ${ }^{25}$ and a pathway towards citizenship. Of the 73,00o refugees who UNHCR reports were admitted to thirty resettlement countries in 2014, the United States resettled 49,000 ( 67 per cent). The total number of refugees resettled in the United States (not all are referred by UNHCR) has numbered about 70,000 per year in the recent past.

BPRM and Us Citizenship and Immigration Services (USCIS) in the Department of Homeland Security share admissions responsibility, and в РRм and the Office of Refugee Resettlement in the Department of Health and Human Services share responsibility for assistance to refugees. The us resettlement program is open only to those who meet the definition of a refugee in the Refugee Act of 1980, which is similar to the UN Refugee Convention definition. The United States does not have a provision for admitting victims of civil war or armed conflict or of massive violations of human rights that do not fall under the Convention refugee definition. However, legislation does permit the designation as refugees of persons still inside their countries of origin if they otherwise meet the eligibility requirements, ${ }^{26}$ which allows processing of refugees in countries of origin, as occurred in the former Soviet Union, Vietnam, Haiti, and Cuba. us law also recognizes that persons who have suffered particularly serious forms of persecution are eligible for admission, even if they are no longer at risk of future persecution.

Refugees must demonstrate they have not established residence in a country of first asylum, and they are subject to security and criminal checks. us legislation specifies that refugees who provided material support to a terrorist organization are ineligible for admission. Terrorist organizations are broadly defined to include most insurgent groups, whether or not they use terrorist means towards their goals, and there is no exception for coercion, so refugees who have been forced to provide material support or paid ransoms to 
free themselves or their relatives are inadmissible for entry into the United States, unless a waiver is granted. Thousands of persons recognized as refugees are awaiting resettlement in countries such as Jordan, Lebanon, Turkey, Ecuador, and Thailand, often in very difficult circumstances, because security checks have not been completed. ${ }^{27}$ Often the problem is a lack of information to confirm that someone is not a security risk, rather than credible documentation that he or she is a risk. ${ }^{28}$

Each year, the president in consultation with Congress determines how many refugees will be admitted each year and how that number will be allocated by region. Priorities for resettlement within regional allocations are: (1) cases involving persons facing compelling security concerns; (2) cases involving persons from specific groups of special humanitarian concern to the United States; and (3) family reunification cases involving close relatives of persons admitted as refugees or granted asylum. ${ }^{29}$ In September 2015 the government announced its intention to increase the ceiling on admissions for Fiscal Year (FY) $2016^{30}$ to 85,00o and to 100,000 in FY 2017, and in advance of the us Leaders' Summit it announced an additional increase to 110,000 for FY 2017 Ten thousand of the additional numbers in FY 2016 would go to resettlement of Syrian refugees. Although still lower than historical highs, this expansion represents a significant increase over resettlement in the years immediately after the September 2001 terrorist attacks when admissions reached a low of 27,000 refugees.

After the November 2015 terrorist attacks in Paris, the decision to increase resettlement of Syrian refugees was met with intense opposition from some state governors and Republican candidates for president. Arguing that terrorists could be resettled along with bona fide refugees, those opposed to bringing Syrian refugees to the country argued that their first concern was the safety of their own populations. They questioned whether the process used in approving refugees for resettlement was sufficiently rigorous to screen out those posing security threats. Governor Chris Christie of New Jersey (also a presidential candidate) went as far as saying that he would not even take a three-yearold orphan-a particularly callous remark in the context of Aylan Kurdi, the drowned three-year-old Syrian boy whose photo captured so effectively the desperation of many Syrian refugees. Since then, several states have filed lawsuits against the federal government for continuing to resettle Syrian refugees, and one state has proposed legislation to hold voluntary agencies that bring refugees from "high-risk," mostly Muslim countries accountable if the refugees commit crimes within five years of admission.

The controversy over resettlement is reminiscent of the debates in the 1930 and could have serious repercussions for us leadership on refugee issues. Without support from Congress and state governors, it would be very difficult for the United States to raise its levels of resettlement much beyond current levels. Had the governors succeeded with their lawsuits, this would have hampered the ability of the president to call upon other countries to significantly increase their resettlement efforts at the summit he hosted in September 2016.

In addition to its resettlement program, the United States operates an asylum program for those who spontaneously arrive in the country and claim refugee status. How the United States handles asylum applications arguably affects its influence on refugee protection worldwide. Attempts by the United States to deter would-be asylum seekers have been duplicated by other countries, as have been efforts to broaden the scope of protection through its initiatives to extend protection on the basis of gender-based persecution.

Between 25,000 and 30,000 asylees are granted asylum each year. ${ }^{31}$ At present, there are significant backlogs of asylum cases awaiting adjudication. The large-scale movement of Central Americans, particularly unaccompanied minors and families with young children, has stretched the capacity of the asylum system in recent years. As the countries of the Northern Triangle (El Salvador, Guatemala, and Honduras) saw significant increases in homicides and other forms of gang violence, many more Central Americans took the risk of transiting Mexico to come to the United States. ${ }^{32}$ During the summer of 2014, the president called the arrival of about 70,000 unaccompanied minors a "humanitarian emergency" that was straining resources for their care as well as adjudication of claims for relief from deportation. The administration was criticized for its policies regarding families with children who were detained for what appeared to be excessive periods. An announcement that the United States would step up resources to deport families who had exhausted their legal appeals drew still further criticism. Opponents argued that many of the families did not have adequate or any legal representation, which can harm the adjudication of their claims.

Like other countries, the United States has used policies to avert the arrival of asylum claimants. Some policies are in the category of "sticks" designed to deter asylum seekers from seeking entry, including mandatory detention and interdiction. For example, us policies to interdict, detain, and deport Haitians seeking entry to the United States have not only been inconsistent with policies toward other arrivals, particularly Cubans, but have served as a negative example for other countries. Others are arguably "carrots." For example, in partial response to the Central American surge in applications, and recognition of the dangers to transiting asylum seekers, the United States put established an in-country processing system through which the children 
of parents already living in the United States could apply for refugee resettlement or other admissions programs from home. Both modes of operation have been replicated by other countries experiencing their own increase in asylum seekers.

On the positive side, the United States can be credited leading on other aspects of asylum adjudications. For example, it led in establishing that fear of persecution by non-state actors can be a basis for asylum if the government of the country of origin is unwilling or unable to protect the applicant. The United States was also among the first countries to provide guidance to asylum adjudicators regarding genderbased persecution, issuing guidelines in 1995.33 These guidelines focused on two aspects of gender and asylum: (1) that persecution can be gendered, as in the case of rape and sexual abuse; and (2) persecution can be on account of gender, particularly in cases involving sexual orientation, domestic violence, and female genital mutilation. ${ }^{34}$

Another model has been us legislation that authorizes persons whose countries of origin are experiencing conflict or natural disasters to remain in the country, even if they had originally entered illegally. Temporary protected status (TPS) applies to persons "in the United States who are temporarily unable to safely return to their home country because of ongoing armed conflict, an environmental disaster, or other extraordinary and temporary conditions." 35 Environmental disaster may include "an earthquake, flood, drought, epidemic, or other environmental disaster in the state resulting in a substantial, but temporary, disruption of living conditions in the area affected." ${ }^{6}$ In the case of environmental disasters, as compared to conflict, the country of origin must request designation of TPS for its nationals.

The designation is still in effect for citizens of Honduras and Nicaragua (since 1998), El Salvador (2001), Somalia (2001), Sudan (2004), and Haiti (2010).37 In 2014-15 alone, new designations were made for citizens of Nepal (earthquake), Syria (conflict), Yemen (conflict), South Sudan (conflict) and Guinea, Liberia, and Sierra Leone (Ebola).

\section{Assessing us Leadership}

In general, the United States leads in assistance and protection of refugees and displaced persons. As discussed, it remains the largest donor to the array of international organizations with responsibilities in this area. Generally, there has been bipartisan support for these contributions to humanitarian programs. Although in recent years, all funding has seen significant cuts, as pressure to reduce government spending has increased, the us budget for refugees has remained largely intact. There has been no effort to remove funding for the refugee resettlement program, despite the controversy over Syrian refugee admissions. These levels of funding, not only for UNHCR but also IOM, UNRWA, ICRC, and other humanitarian agencies, effectively gives the United States veto power when setting the priorities of these organizations.

us funding provides both multilateral and bilateral assistance, giving some discretion to the international organizations to determine how to best meet the needs of refugees and displaced persons. At the same time, it has earmarked funds to encourage these agencies to address what the United States perceives as unmet needs. The Safe from the Start initiative is a case in point, as has been long-time us advocacy for the protection of refugee women and girls.

The United States has pushed initiatives to expand protection for other populations, most recently migrants in countries in crisis. Only a handful of member states have taken on initiatives of this sort-the leadership of Norway and Switzerland on the Nansen Initiative Global Protection Agenda for those who cross borders in the context of natural disasters and the effects of climate change comes to mind. In the case of Nansen (as well as the Guiding Principles on Internal Displacement and others), the us government took a keen interest but chose not to lead. By contrast, in each of these situations, Us non-governmental organizations and experts played important roles in providing intellectual guidance to the initiatives.

The convening power of the us government has played an enormous role historically and continues to be a principal reflection of its leadership within the field. This power does not appear to have diminished, as witnessed by the response to President Obama's decision to host a summit on refugees at the 2016 General Assembly. Over fifty governments, many represented by heads of state or government attended the Leaders' Summit-a significant achievement, when considering that governments could attend only if they had made significant new commitments.

Nevertheless, there are reasons to be cautious about us leadership. While it is unlikely that the United States will soon lose its status as principal donor and one of the principal strategists on tackling displacement issues, its ability to generate new resettlement offers is less clear, as is its ability to increase its own resettlement levels. Whenever resettlement in the United States has been a political football, rather than a testament to humanitarian, foreign policy, and domestic constituency interests, it has suffered. Continuing political leadership from the supporters of a robust resettlement effort will be essential if the program is to grow, as the need for resettlement grows and respond efficiently and effectively to new demands.

The numbers who are resettled today are significantly lower than those of the early 1980 os and well below the need for global resettlement. The multiple security checks imposed on applicants for resettlement leave applicants 
neither approved nor denied but instead awaiting clearance. The asylum system still has significant gaps, particularly in provisions such as interdiction, detention, arbitrary deadlines, and security checks that make them inaccessible for too many asylum seekers with credible claims for protection.

What does all of this mean for us leadership in the refugee regime? By most measures, the United States is still the dominant power, whether measured by influence, money, or admission levels. Unlike in many other policy spheres, the United States has often preferred to operate through multilateral approaches in encouraging protection and assistance for refugees and displaced persons. The us government has supported other governments that wish to lead in important international initiatives to enhance protection. Having other prominent states lead in the refugee regime is fully consistent with US strategy. That having been said, however, there is little likelihood that major changes in policies or shifts in refugee priorities would succeed without us agreement to these practices.

\section{Notes}

1 Bruce Jones and Thomas Wright, "The Foreign Policy Essay: The State of International Order," Lawfare Institute and Borrkings, 2014. https://www.lawfareblog.com/ foreign-policy-essay-state-international-order.

2 For analyses of factors influencing us participation in and impact on multilateral organizations in general, see Rosemary Foot, S. Neil MacFarlane, and Michael Mastanduno, eds., us Hegemony and International Organizations: The United States and Multilateral Institutions (Oxford: Oxford University Press, 2003). Although none of the chapters address the refugee regime, the analyses of the domestic and external forces that have affected us leadership in other domains, such as the multilateral economic systems, are similar to those highlighted in this article.

3 An Act to Regulate the Admission of Aliens to, and the Residence of Aliens in the United States, 1917, http://library .uwb.edu/static/usimmigration/39\%20stat\%20874.pdf.

4 Woodrow Wilson, "Veto Message on HR 10384," in President Wilson: State Papers and Addresses 356-8 (New York: Review of Reviews, 1918)

5 Susan Martin, A Nation of Immigrants (Cambridge: Cambridge University Press, 2011).

6 Ibid.

7 N.H. Haynes, ed., The Speeches of Adolf Hitler, April 1922-August 1939 (Oxford: Oxford University Press, 1942), 719-20.

8 The term parole has different connotations. Although it sometimes refers to the release of immigrants from federal custody, in this context it "refers to the practice of letting a noncitizen physically into the country for immigration law purposes." Hiroshi Motomura, Americans in Waiting:
The Lost Story of Immigration and Citizenship in the United States (Oxford: Oxford University Press, 2006), 58. It applies when the non-citizen does not meet the requirements for admission but the attorney general determines that for humanitarian, foreign policy, or other reasons, he or she should be allowed to enter.

9 Public Law 86-648. Joyce Vialet, A Brief History of us Immigration Policy, Report 8-223 EPw (Washington, DC: Congressional Research Service, 1980), 23, https://digital.library .unt.edu/ark:/67531/metacrs8492/m1/1/high_res_d/8o223_1980dec22.pdf.

10 Concerned that emigration remained elusive for many religious minorities in the Soviet Union, particularly Soviet Jews, the United States passed legislation known as the Jackson-Vanik Amendment that prohibited normal trade relationships (referred to as Most Favoured Nation status) with countries that prevented their citizens from exiting. Passed in 1974, the legislation remained in place until 2012.

11 Gil Loescher, The UNHCR and World Politics: A Perilous Path (Oxford: Oxford University Press, 2001), 35.

12 IRO Constitution 1946.

13 Loescher, UNHCR and World Politics.

14 The organization that was most affected was the International Labor Organization, which had robust membership from Communist countries. Since its establishment in 1919, the ILO had been involved with finding employment for displaced persons but was not eligible for us funding for such programs in the 1950 .

15 Gil Loescher, Beyond Charity: International Cooperation and the Global Refugee Crisis (New York: Oxford University Press, 1993).

16 Edward O’Connor, “The Brussels Conference," Social Service Review 26, no. 4 (1952): 399-404.

17 UN General Assembly Resolution 302, A/RES/3O2 [IV] 8 December 1949, art. 5.

18 Gene M. Lyons, "American Policy and the United Nations' Program for Korean Reconstruction," International Organization 12, no. 2 (1958): 181.

19 Ibid., 182.

20 Us State Department, "Bureau of Population, Refugees and Migration, FY2016, Summary of Major Activities," 2016, https://www.state.gov/documents/organization/265231.pdf.

21 William Burns, "U.S. Intervention at UNHCR Excom HighLevel Segment," 2013, HumanRights.Gov, http://www. humanrights.gov/dyn/u.s.-intervention-at-unhcr-excomhigh-level-segment.

22 New YorkDeclarationfor RefugeesandMigrants, un General Assembly A/71/L.1:10, http://www.un.org/ga/search/view_ doc.asp?symbol=A/71/L.1.

23 A term coined by Sir Peter Sutherland, the secretary general's special representative on international migration. See "Remarks by Peter D. Sutherland, Special Representative of the UN Security General, on International Migration, Delivered at the UN DESA Coordination Meeting," 25 February 2016, http://www.un.org/en/development/desa/ 
population/migration/events/coordination/14/documents/ presentations/Peter_Sutherland_14CM.pdf.

24 U.S. State Department, "Strengthening the International Response to the Global Refugee Crisis: Fact Sheet of the Office of the Spokesperson, Washington, DC, January 22, 2016," http://reliefweb.int/report/world/strengtheninginternational-response-global-refugee-crisis.

25 In the United States, refugees have a one-year conditional admission and apply for permanent resident status after that period.

26 Stephen Legomsky, "Refugees, Asylum and the Rule of Law in the USA," in Refugees, Asylum Seekers and the Rule of Law: Comparative Perspectives, ed. Susan Kneebone, 12270 (Cambridge: Cambridge University Press, 2009).

27 Andrew I. Schoenholtz and Jennifer Hojaiban, "International Migration and Anti-Terrorism Laws and Policies: Balancing Security and Refugee Protection," policy brief no. 4, Institute for the Study of International Migration, Transatlantic Perspectives on Migration, 2008.

28 During a field visit to Amman, Jordan, in January 2012, the author interviewed Iraqi refugees in this situation. They had met all requirements for admission to the United States, but no decision had been made on their security clearance.

29 Andorra Bruno, Refugee Admissions and Resettlement Policy (Washington, DC: Congressional Research Service, 2012).

30 FY 2016 runs from 1 October 2015 to 30 September 2016.
31 Daniel C. Martin and James E. Yankay, "Refugees and Asylees: 2013," Annual Flow Report (Washington DC: Department of Homeland Security, 2014), http://www.dhs .gov/sites/default/files/publications/ois_rfa_fr_2013.pdf.

32 UNHCR, Children on the Run: Unaccompanied Children Leaving Central America and Mexico and the Need for International Protection (Washington, DC: UNHCR, 2014).

33 Susan Martin, Refugee Women, 2nd ed. (Lanham, MD: Lexington Books, 2004).

34 Ibid.

35 U.S. Immigration Act, 1990.

36 Ruth Ellen Wasem and Karma Ester, Temporary Protected Status: Current Immigration Policy and Issues (Washington, DC: Congressional Research Service, 2011).

37 In 2007, TPs ended for Liberians, but the administration decided to grant Deferred Enforced Departure (DED) for those who had had Temporary Protected Status.

Susan F. Martin is professor emeritus at Georgetown University. The author may be contacted at susan.martin.isim@georgetown .edu.

Elizabeth Ferris is research professor at the Institute for the Study of International Migration at Georgetown University. The author may be contacted at elizabeth.ferris@georgetown.edu. 